\title{
Contemporary Nigeria and the Deficit of Deliberative Democracy: Exploring the Indigenous Value of Àgbájọ ọwọ́ as Collegiality
}

\author{
Ronald Olufemi Badru \\ Department of Politics and International Relations \\ Lead City University, \\ Ibadan, Nigeria \\ femmydamak@gmail.com
}

\begin{abstract}
The paper advances three groups of interrelated claims. First, a fundamental deficit of democratic practice in contemporary Nigeria is that electoral choices/candidates are largely disconnected from the spirit of vibrant deliberation/consideration by the Nigerian demos. Second, candidates that emerge tend to be more parochially disposed to serving the interests of the political sponsors, rather than working towards the promotion of the common good. Third, to address the problem of the research, it is argued that well-meaning, democratically conscious Nigerians should practically embrace the indigenous value of àgbájo owo as as collegiality to resist electoral choices/candidates of the noted politically influential elites. As one of the socio-moral values of an ideal Yoruba persona, or omọlúwàbí, àgbájo ow wọ underscores the critical point that the realty of the common good properly derives from a rational collaboration of the members of a political collectivity. Ultimately, this understanding of collegiality helps in the promotion of deliberative democracy and its benefits in Nigeria.
\end{abstract}

Keywords: Àgbájo ọwọ́, Collegiality, Deliberative Democracy, Ọmọlúwàbí, 


\section{Introduction and the Problem Statement}

One of the fundamental principles of the philosophy of democracy is that the ultimate power of political administration in the state ought to be the outcome of a decision made by the people as free moral agents. This means that the people should decide, without coercion, on how to fix two interrelated significant questions of state administration: (i) who is to rule them, and (ii) how $\mathrm{s} /$ he is to rule them. The first question concerns the choice of leadership of the state, and the second question relates to the procedural course of administration of the state by the leadership, were the latter to be regarded as legitimate (Badru and Oloruntobi 2016, 163). But, it is uncomplimentary to note that the basic principle adverted to is superficially emphasized in the democratic experience in Nigeria.

After the second period of anti-democratic military incursion into the political space in Nigeria, ${ }^{1}$ which had ingloriously begun on December 31, 1983, civil rule re-emerged with euphoria in 1999. Since then, four different rounds of general elections in Nigeria had been held, in 2003, 2007, 2011, and 2015. Needless to say, the last general elections brought in the present regime of the All Progressives' Congress (APC) at the national level, taking over from the erstwhile political dominance of the Peoples' Democratic Party (PDP), which had been in power at the national level since 1999. Cursorily, the foregoing could be taken as a testimony to the progress of liberal democracy in Nigeria. But, one must be critically minded so as not to commit the fallacy of hasty generalization, by unthinkingly jumping to conclusions. Granted, multi-party politics and periodic elections are key to the progress of liberal democracy anywhere, and Nigeria is not an exception. However, one must also duly note that the Nigerian demos, the basis of both multiparty politics and periodic elections, are still covertly being relegated. The logic is simple enough. A fundamental deficit of democratic practice in contemporary Nigeria, I argue, is that electoral choices/candidates are largely disconnected with the spirit of vibrant deliberation/consideration on the part of the Nigerian demos. Rather, electoral choices/candidates are largely foisted on the people by a few influential members of the contesting political parties. There is a justified contention that the practice obtains at the level of party primaries, and at the level of public/general elections. Similarly, it could also be experientially argued that the candidates, which emerge at the two levels, tend to be more parochially disposed to serving the interests of the political patrons rather than working toward the promotion of the common good, which is the ultimate normative telos of any democracy worthy of the term. Considering this, at least,

1 The first period of military interventionism in the political space in the history of Nigeria was between 1966 and 1979. 
three values of what one could regard as collegiality (a significant value in any actual democracy) are inverted: (i) the value of truly collective deliberation in the decision-making process of public life, (ii) the value of promoting the common good, and (iii) the epistemic/cognitive and socio-political development of the citizen-participant in democratic deliberation.

Given these, my argument is that well-meaning, democratically conscious Nigerians should practically embrace the indigenous value of àgbájo owó as collegiality, which is derived from Yorùbá-African ethics and cosmology, to resist electoral choices/candidates that are handed out by noted politically influential elites. One of the socio-moral values of omọlúwàbí, an ideal Yorùbá persona (see Dasylva 2016, 65), is àgbájo ọwọ, which emphasizes the collectivity of minds to achieve social progress and ultimate development. Contextually, it underscores critical point that the realty of the common good properly derives from a rational collaboration of the members of a political collectivity, but not through the pursuit of the sectarian interests of some few influential members of the society. Thus, this value should be the basis of acceptance or rejection of electoral choices/candidates in Nigeria, rather than the sectarian interests of a few political elites within those parties. Eventually, with this understanding of collegiality, the course of deliberative democracy and its benefits would be promoted in Nigeria.

While there has been some scholarly research (that will soon be shown) on the concept of àgbájo owó, my approach and analysis differ from them on three grounds: (i) most of these works are more ethnographic than philosophic; at best, they are tangentially philosophic, far from an attempt at unearthing some deep African and general philosophic values of the concept; (ii) none of the previous works applies the concept to elaborately interrogate the concept of deliberative democracy in Nigeria; and (iii) none of the works grapples with some likely objections or proffers responses to the political application of the concept.

The central research questions in this essay are the following: (i) What constitutes the deficit of deliberative democracy in Nigeria? (ii) Why is the value of deliberative democracy important in Nigeria? (iii) What constitutes omọlúwàbí, its value as well as its central ethical elements? (iv) How could àgbájọ ôwó as collegiality localize and operationalize the idea of deliberative democracy in Nigeria? (v) How could the concerns of desirability, plausibility, and feasibility about àgbájo ọ wọ as collegiality be addressed?

The essay is divided into six sections. section I introduces the discourse and also gives the problem of the study; section II focuses on some preliminary conceptual explications; section III examines the deficit of deliberative democracy in contemporary Nigeria; section IV clearly articulates the general philosophic desirability of the thesis of the study, before focusing on the 
specific socio-political desirability of the thesis in Nigeria; section V considers likely objections to the main argument of the work and equally responds to these objections in a rational way, and section VI summarizes and concludes the study.

\section{The Conceptual Framework: A Preliminary Discussion}

In this section, I attempt a critical interrogation of the key concepts that frame the discourse, which are collegiality, deliberative democracy, omolúwàbí, and àgbájo ọwó.

Collegiality: Right from the outset, one must note that the concept of collegiality emerges from a background of complexity. For Cavanagh, collegiality refers to an association of colleagues $(2010,1)$, but beyond this general idea its meaning is far more complex. But, this does not mean that collegiality is beyond our comprehension. In one framework, collegiality is related to the dynamics of the Socratic dialogue. Arguing from this angle, Van Hooft states that the Socratic dialogue is a collective attempt to find the answer to a fundamental question, the question being the center of the dialogue. He notes:

Although these questions are general in their nature, they are not discussed with reference to philosophical theory. Rather, the question is applied to a concrete experience of one or more of the participants that is accessible to all other participants. Systematic reflection upon this experience is accompanied by a search for shared judgements and reasons...The dialogue aims at consensus. It is not a simple or easy task to achieve consensus. Effort, discipline and perseverance are required. Everyone's thoughts need to be clarified in such a manner that participants understand each other fully. The discourse moves slowly and systematically, so that all participants gain insight into the substance of the dialogue. Participants can also engage in metadialogue, which is about the process and strategies of the dialogue (van Hooft 2011, 20-21)

The Socratic dialogue provides a framework for looking at collegiality. Another concerns what we can call the ontology of collegiality. For Cavanagh:

Collegiality is associated with concepts such as participation, loyalty, trust, respectful (but perhaps firm) exchange of views, openness and transparency in decision making and power-brokering. A common understanding of collegiality pays regard to the desirability of the notion of sharing-of influence, ideas, responsibility and creativity. A collegiate climate is one in which the characteristics mentioned above are not only genuine and 
evident, but are considered prerequisite and defining characteristics of the collegiate fabric of the context in question. To this extent collegiality has an association with fairness and social justice in that it embraces many of the key characteristics of an open space for interpersonal engagement and human communion. The collegium, i.e. the space in which collegiality is practised and expressed, is concerned with social justice insofar as a genuinely and normatively developed collegiate environment embraces inclusion, and protects individual right to opinion and audience $(2010,3)$.

Conceptually relating both the Socratic dialogue and collegiality, as rendered above, we could notice some significant commonalities, such as the all-inclusivity of the environment of dialogue, the concreteness of the issue of discussion, the correlative openness and transparency of the participants, equality and equity involved in the process, predominance of rationality in the exchange of views, criticality of submissions and acceptances, and so on.

Drawing on these conceptual commonalities, one could aver that collegiality is a philosophy of learning and knowledge dissemination about life, which prioritizes, centralizes, or emphasizes a systematically conducted collaborative reasoning or reflection, which focuses on arriving at a collectively well thought-out conclusion, perhaps, evolving from the epistemic ground that since no one is a fount of knowledge, a more robust knowledge better derives from a collaborative collectivity of minds. This epistemic view of collegiality, if extended to the realm of decision-making in public life, entails that any governance decision that affects and impacts the life prospects of the citizenry in a state should be an outcome of a collectivity of minds. Put more clearly, this normative sense of collegiality prescribes that any form of decision-making in public life that affects most of the citizenry should be conducted within the framework of dialogical, rather than monological reflection. This is distinguished from a non-normative sense of collegiality, which (merely) sociologically articulates the operation of collegiality, without necessarily ascribing any normative ideal to it. It is this normative sense of collegiality that is more interesting in the present discussion of deliberative democracy in Nigeria, which is contextually adopted.

Deliberative democracy: This phrase involves two components: "deliberation" and "democracy." Deliberation entails evaluating the strengths and weaknesses, relative to a position, with a view to arriving at a considered position. Thus, if the strengths outweigh the weaknesses, the position is adopted. But, if the weaknesses outweigh the strengths, then, the position is rejected. However, to use the words of Cohen, democracy is all about making decisions along the lines of "interests and judgments" of the agents that are the focus of the decisions $(2009,249)$. If "deliberation" and "democracy" are 
conceptually harmonized, then one could regard deliberative democracy as a form of thinking that normativizes rational deliberation in the process of decision-making in public life; deliberation being understood as a normative ideal and as a test for democratic legitimacy (Cortina 2010, 137). According to Dryzek, the essence of deliberative democracy is the idea that the legitimacy of any collective decision should be sought in reflective acceptance on the part of those subject to the decision $(2004,72)$. But, it is one thing to note the legitimating importance of reflective acceptance in the context. There seems to be a bigger question of how could or should this reflective acceptance be obtained?

Anticipating the question, Dryzek states that the best way to assure this acceptance is: (i) to define the relevant public as those affected, and (ii) to allow these individuals access (directly or indirectly) to consequential deliberation about the content of the decision at hand $(2004,72)$. If, therefore, the deliberation is appropriately conducted and it is publicly inclusive enough, drawing on the Dryzek's sense, then the post-deliberation decisions arrived at, and the public outcomes of the decisions made, are said to have "rational acceptability," according to Cortina $(2010,137)$. Lastly, to reiterate, one could state that deliberate democracy is committed to specific rational understandings of both the means and the ends of public decision-making. At the level of the means, it prioritizes collective reasoning as the determinant of: (i) the constitution of the agency of deliberation, (ii) the operational procedure of the agency, and (iii) the agenda-setting of the public decision-making exercise. At the level of the ends, it prioritizes serving the interests of the people as reasoning agents, the people that jointly subscribe to the political community within which the public decision-making takes place.

This account of deliberative democracy is sufficient to set the template for our analyses of the Nigerian democratic experiment; though, one should acknowledge that the democratic theory literature is rife with robust and interesting discussions between the proponents of deliberative democracy (see, for example, Hicks, 2002; Cohen, 2009), on the one hand, and the opponents of it (see, for example, Gaus, 2008; Hardin, 2009), on the other.

Omọlúwàbí: For Badru, in Yoruba ethics, omọlúwàbí is one who has cultivated the epistemic/cognitive virtues of thoughtfulness, and consultation; the moral-social virtues of tolerance, respectfulness, lovingness, sincerity; social responsibility; the moral-linguistic virtue of decency in expressions and the moral-personal virtues of commitment to duties, and moderation in conduct $(2017,10)$. If we emphasize the multi-dimensionality of the 
virtues predicated of omolúwàbí, then we could state that such personality is a positively complete, responsible and responsive agent in society. Now, since it takes all the foregoing to be regarded as a person of character in Africa, then we could also state that the concept of omolúwàbí is coherent with the essence of African ethics, which is character-inclined (see Gyekye, 2010). Given this, one could similarly state that the brief account of omolúwàbí correlates with some given conceptions of èniyàn in Yoruba cosmology. According to Dasylva, the concept of èniyàn refers, among other things, to "the quality of the human mind, or that which foregrounds a refined intellection, and perception of, and attitude to, life and living" as well as "such principles or values that define and determine the degree and quality of humanness in a personality" $(2016,70)$.

The concept of àgbájo owo (joining of hands; collectivity of efforts), just like that of omolúwàbí, is grounded in Yoruba philosophy. This concept derives from a well-known Yorùbá saying:

Àgbájo ọwó
La fi ń sọyà
Àjèjé ợọ kan
Kò gbẹ́rù d'órí

To beat a chest

The whole hand is required

A part of the hand

Cannot lift up a heavy load to the head (Coker and Coker 2009, 7).

Although, it might be claimed that there is nothing philosophic about this rendering and its interpretation, this claim, however, is not true on further reflection. One could rightly state that the concept of àgbájọ owọ is ontological, moral and epistemic. It is ontological, given that it is continuous with African ontology of the human person as a relational, but not as an atomistic, being. It is moral, given that it normativizes cooperative, rather than antagonistic interaction, in society; it takes cooperative interaction as a morally ideal way of relationship-building between the self and the other, a better mode of human social existence, and this is significant in African ethics. Moreover, it emphasizes what one could call epistemic complementarity, which implies that the knowledge of the self and that of the other, if brought together, are complementary. It stresses that no one is a fount of knowledge, and this is also co-extensive with the idea of essentiality of complementarity in the knowing 
process in African epistemology (see Chapters 3, 4, \& 5 of Coetzee and Roux, 2003). This understanding is rendered thus:

"Omodé gbọn, àgbà gbọn, l'a fi dá ilẹ Ifẹ."

The combined wisdom of the youth and the elders were used to create Ifẹ (Oyeyemi 2016, 4).

If we consider the epistemic contents of the rendition, then we could state that just as a collectivity of the wisdom of the youth and the elders was significant in the founding of Ife, the ancestral home of the Yorùbá, it could as well lead to the founding and sustaining of a deliberatively vibrant democratic society in Nigeria. It is a truism that collective knowledge as collective wisdom could contribute to the development of any society.

Having attempted to separately examine both ọmọlúwàbí and àgbájọ ọwó, one should show their logico-semantic connection. If we agree that the concept of omolúwàbi entails, among others, the epistemic/cognitive virtues of thoughtfulness and consultation, according to Badru (2017), then it necessarily binds with àgbájo owo o. The reasoning is simple enough. The value of thoughtfulness in a person invariably suggests epistemic limitations. This means that such a thoughtful person must know that his/her knowledge about anything in life is limited. Therefore, to rationally address this epistemic limitation, he or she must also know that he or she would be better epistemically complemented through a consultation with the other. This shows that thoughtfulness and consultation are conceptually correlative; though, the former is mental, and the latter is largely verbal and demonstrative. If the given premises are true, then the conclusion is also true that a belief in àgbájo ow wo is a definitive part of being an omolúwàbí. And, since consultation and deliberation are lexically correlative, then an omolúwàbí in public life, who is committed to àgbájo ọọ́, should also be consistently committed to a dialogical conception of collective decision-making, and this is what deliberative democracy entails.

Virtue and value: Given the importance of virtue and value to the thesis that is being advanced, the contextual meanings of the two concepts should be discussed. Contextually, virtue is understood as excellence of conduct, a practical output of conscientious cultivation over a period of time, while value is understood as that which is desirable, as distinguished from that which is actually desired. Critically, what is desirable may sometimes not correlate with what is actually desired; at other times, what is actually desired may happen to be what is desirable, for example, to a mature, morally conscious agent. Moreover, virtue and value are morally connected, given that excellence of conduct ought to be that which is desirable to a mature, morally conscious agent 


\section{Contemporary Nigeria and the Deficit of Deliberative Democracy}

As briefly noted in the introduction, the central argument here is that, while the so-called liberal democratic practice in Nigeria has been largely denuded of the influence of a very important aspect of it, what we would call the demos' factor, it has largely foregrounded the importance of some influential and powerful figures or elites within the political parties. Many scholarly works have affirmed this, leading researchers to negatively describe the democratic practice in Nigeria as "clientele democracy (Kura, 2014);" "the wrong practice of democracy (Ajayi and Ojo 2014, 113);" "choiceless" democracy (Omotola, 2007,134); "elitist democracy" (see Albert 2005, 101); "mockery of democracy" (Aluaigba, 2002); "pre-bendal political democracy" (Joseph, 1999) to mention a few. In short, one could rationally assert that the democratic political space in Nigeria is now largely controlled by political godfatherism, rather than the demos' factor. Scholars have attempted to unravel the nature of the political godfathers, which negate the demos' factor in the practice of democracy in Nigeria.

According to Omotola, "godfathers" are those who have the security connections, extended local links, enormous financial weight, and so on, to plot and determine the success of a power seeker at any level of a supposedly competitive politics $(2007,135)$. The complex process of doing this from "womb to tomb" is famously known as "godfatherism." Albert builds upon Omotola's conception:

Political godfathers use their influence to block the participation of others in Nigerian politics. They are political gatekeepers: they dictate who participates in politics and under what conditions. The role of such people is highly injurious to the advancement of popular, participatory democracy in Nigeria. Political godfathers are responsible for most of the pre-and post-election violence that we have seen in Nigeria...He makes it difficult for members of his political party who fail to recognize his authority to get nominated for elective offices. Those who recognize his 'worth' thus go to him to be 'specially anointed' and things work positively for them automatically (Albert 2005, 82, 85).

Albert then goes on to mention five types of political godfathers that have dominated the political space in Nigeria:

The first type is "geo-political" or "ethnic" organizations that arrogate to themselves the right to decide who represent their jurisdiction in 
government...The second category consists of "geo-political" or "ethnic father figures". These are some prominent individuals within some geo-political or ethnic organization who are popularly respected by members of the movements they belong to, as a result of some past "nationalist activities"...The third category of political godfathers consists of some rich Nigerians who see sponsorship of political candidates as a source of upward social and economic mobility...The clients are usually people who are interested in winning elections 'by all means' but who do not have the grassroots support, the money, or the violent dispositions for winning elections. The godfather assures the candidate of easy availability of this possible assistance in exchange for some personal benefits for the godfather after election...The fourth type of godfathers consists of those who only deal with rich clients. Such people, for want of appropriate terminology, can be said to be "political entrepreneurs". They live on politics. The only asset they have is that they are well schooled in the tricks of winning elections among the grassroots people...The fifth type of godfathers consists of rich patrons who are willing to provide what it takes for either rich or poor clients to win elections. He is willing to provide poor candidates with money and logistical support to win elections and he is ready to contribute to the campaign funds of rich candidates as well as provide them with logistical support (Albert 2005, 90, 91).

As noted by Albert (2005), the influence of the so-called political godfathers, which counters the demos' factor, can be seen in almost every aspect of Nigeria's democracy, a significant aspect of which being elections. Adeoye states that the power of patronage in Nigeria has a big influence on election results, and the underlying proposition is that the actual source of power lies neither in the people's votes nor their power to determine their leaders, but rather in the resources of politicians $(2009,269-270)$. Therefore, we could agree with Aluaigba, who graphically notes that since 1999, the outcomes of elections in the country have scarcely reflected the will of the voters owing to an avalanche of electoral malpractices $(2016,137)$. Osakede and Ijimakinwa also agree with the previous studies by showing the geographic spread of political godfatherism in the Nigerian democratic practice (2016, 5). According to them,

The political actors and their political godfathers were on the verge of contending "who is who" in their states. Prominent among the kingpins in the states are Modu Ali Sheriff (Senator) vs Governor Mala Kachalla of Borno; Olusola Saraki vs Late Mohammed Lawal, Governor of Kwara State; Jim Nwobodo (Senator) vs Governor Chimaroke Nnamani (Enugu State); 
Emeka Offor (Chief) vs Governor Chinwoke Mbadinju (Anambra State); Abubakar Rimi (Alhaji) vs Governor Rabiu Kwankwaso of Kano State and Lamidi Adebibu vs Governor Rasheed Ladoja of Oyo State, to mention a few (Ibid).

It is really disheartening to note that the list of political godfathers and their godsons keeps multiplying with negative vibrancy in the practice of democracy in Nigeria. But, the basic question still is: how do the godfathers undermine deliberation in the democratic experiment in Nigeria and how does this further discredit what we call "democracy"? The answer to this question is simple. Godfathers usually impose their political candidates on other political party members in a way that cancels any attempt to subject the imposed candidates to critical deliberation, on the part of other party members (on the one hand) and on the part of the demos (on the other hand), relative to the presence or absence of moral and epistemic capital of the imposed candidates. By moral capital, in the contextual sense, I mean a mix of virtues and values that an agent ought to embrace and develop, which would make him or her to be socially responsible and responsive (such as fairness, transparency, accountability, responsibility, efficiency, other-responsiveness, courage to do good, ethical patriotism, etc.). By epistemic capital, in the contextual sense, I mean requisite knowledge infrastructure, that is, both theoretical rationality (ideational knowledge of what is to be done) and technical rationality (practical knowledge of how it is to be done) that must be harmonized for functional effectiveness in service. It is argued that where the presence of these forms of capital is compromised by political imposition through godfatherism, then effectiveness in terms of quality service to the people is also compromised. It is needless to state that such a democracy would invariably attract negative acclaim.

But, if it is reasonable to aver that Nigeria is falsely democratic, then what could be rationally done to alter things, that is, to make Nigeria a truly democratic state? This constitutes the next discussion.

\section{Àgbájọ Q̣ọ́ and the Collegial Imperative in Nigeria}

Here, there are two basic objectives in focus. The first is to expose some significant philosophical values of àgbájo owọ, in the general sense; the second is to show its pragmatic desirability in terms of its socio-political and epistemic/ cognitive significance in the deliberative sense of democracy in Nigeria. The first is important, given the fact that, if àgbájo owo is is to have any significance as collegiality in the theoretical and democratic sense, then its general philosophic value must be fore-grounded, having earlier shown its desirability 
within African philosophy. The second is required because it socio-politically contextualizes the relevance of àgbájo ọwọ́ in Nigeria.

\section{General philosophic values}

From the foregoing, it becomes apposite to examine the fundamental philosophic values of àgbájo ow wọ. Metaphysically, the idea of àgbájọ ọwọ is committed to the thinking that the being of the other must come into necessary unity with the being of the self to properly ensure the evolution of an appropriate idea of the common good as well as the practical realization of the idea of the common good in society. Put differently, it recognizes the being of the other as a significant contributor to the common development of a robust idea of the common good, emphasizing in the process the idea of ontological egalitarianism; that the self and the other are ontologically equal as social beings.

In logico-epistemic terms, àgbájọ owọ also expresses a commitment to the cognitive value that knowledge is neither a preserve of the self, nor that of the other; rather, knowledge is best acquired and developed when the self and the other act in complementarity, emphasizing in the process the idea of epistemic egalitarianism of the self and the other, that the self and the other are epistemically equal in society. It is expressive of the notion that a collectivity of rationalities may be more profound than solely that of the self or the other.

Morally, àgbájo ọwọ takes the boundaries and the benefits of moral community as necessarily, but not contingently, embracive of the other, apart from the self, emphasizing in the process the idea of moral egalitarianism. This is the idea that the self and the other have equal moral worth and, by virtue of this, they are also moral agents on equal terms.

When applied to the feasibility of deliberative democracy in Nigeria, the discourse on collegiality assumes a significant dimension. The contention here is simple: àgbájo owọ as collegiality should be embraced in Nigeria because of its socio-political and epistemic/cognitive telos. These would be discussed, using the lexical terms of "argument" and "thesis," the latter being contextually used a sub-set of the former.

\section{Argument I: Àgbájọ ọwọ́ and its socio-political importance in Nigeria}

The first thesis stresses the promotion of true and functional citizenship: Part of the duties of a true, functional citizen is to actively and meaningfully participate, if given the necessary opportunities, in the decision-making affairs of his or her state. Therefore, a vitiation of these opportunities constitutes a counter-vision to the moral development of true and functional citizens in the political collectivity concerned. If true and functional citizenship is one 
of the values for the existential continuity of a state as a unit, then all obstacles in its path are politically evil, and they must be rejected. Likewise, all efforts to promote it must be embraced and encouraged. To this extent, since àgbájo ow ọ contributes to the development of true and functional citizenship, given that it provides the opportunities for willing Nigerians to actively and meaningfully participate in the decision-making process in public life, then it is politically expedient and should be promoted.

The second thesis insists on indigenous solutions to local problems: The point here is simply that àgbájo owo provides a significant public forum for Nigerians to supply indigenous socio-political solutions for local socio-political problems. The outcomes of the public deliberations, to which all interested rational people are given unrestricted access, would serve as the indigenously generated solutions to basic socio-political problems bothering Nigeria, such as: How do we identify and separate rogue politicians from politicians that are truly committed to what one could call "common social utility"? How could average Nigerians functionally determine the contents and the directions of public policies in Nigeria? This is an autochthonous democratic arrangement that ought to be publicly promoted in Nigeria, rather than always foisting on the country basic socio-political recommendations that have been generated from foreign political climes, regardless of the plausibility and the applicability of the political recommendations within the Nigerian context.

The third thesis is a promotion of intra-party democracy: The point here in favor of àgbájo ow ọ as collegiality is that, freely allowing public deliberations on important intra-party political decisions, such as "who is to be chosen at the level of party primaries," and taking the outcomes of the public deliberations seriously, even before elections are conducted, go a long way in better entrenching more intra-party democracy in Nigeria. The logic is that it reduces the influence of godfatherism in the injection of mere political opportunists in the general electoral race.

The fourth thesis references an increased emphasis on the demos' factor: The claim here is that, for years, the influence of the demos' factor, a central feature of any democracy, has been removed from the realm of socio-political decision-making in Nigeria, which claims to practice liberal democracy, and Aluaigba (2016) aptly noted this above. To this extent, the value of àgbájọ owo now opens up to many, rather than restricts to a negligible few, opportunities for the demos' factor to be central to the process of democratic decision-making in Nigeria, relative to the choice of candidates in elections and, subsequently, election results. Specifically, the demos' factor becomes the active determiner, but not the passive recipient, of elections' results in Nigeria. If the third and the fourth thesis are combined, then Nigeria would witness a more inclusive democracy than we have ever experienced in the country. 
The fifth thesis facilitates a basic African contribution to the discourse on democracy: The point here is simply that a commitment to, and a successful operationalization of, the value of àgbájo owó within the political space in $\mathrm{Ni}$ geria will ultimately glocalize the Yoruba-African value, showcasing that there are autochthonous values of note in Africa, which could contribute meaningfully to the discourse of democracy, in general, and deliberative democracy, in particular.

\section{Argument II: Àgbájọ ọwọ and the epistemic/cognitive importance of Nigerians as citizen-participants}

The first thesis speaks to the promotion of epistemic/cognitive competence in political reasoning and analysis: The point here is mere common-sense: practice makes perfect. If willing, average Nigerians periodically publicly participate in deliberations on decision-making, relative to public life, then the epistemic/cognitive virtues/skills of critical thinking, deep analyses of problems before reaching conclusions on their solutions, open-mindedness to issues, receptiveness to the views of the other, carefulness in forming beliefs, etc., of those regular participants tend to be further, practically, improved. These virtues/skills are practically developed in the process of the participants' thinking very hard to contribute actively and meaningfully to the deliberations, such as forming true beliefs, rationally advancing positions from the beliefs, and giving reasons the beliefs are true and the positions are rationally derived from the beliefs. This practical turn invariably also deepens and widens their scope of socio-political reasoning and socio-political analysis. To this extent, non-public recognition of àgbájo owó, which fosters the atmosphere for the development of these epistemic/cognitive virtues/skills, may correlatively vitiate the development of a high level of socio-political reasoning and socio-political analysis of the willing rational Nigerians as moral agents.

The second thesis demands the promotion of a good epistemic hearer in the Nigerian-as-participant: The point here is that the value of àgbájo ow oo within the political space in Nigeria also creates a forum for Nigerians-as-participants to practically develop the epistemic/cognitive virtue of attentiveness (attentively listening to the other), before making responses, and this is one of the virtues of a good epistemic hearer. A good epistemic hearer, contextually, is a conscientiously listening person, who is always ready to hear the other out, one who is always ready to benefit cognitively, by paying close attention to all the necessary details, so as not to wrongly impute/ascribe to the other what he or she does not intend, before making any calculated response. In short, a good epistemic hearer is a moral agent, who always believes that any 
other moral agent is worthy of epistemic respect, in their cognitively related interaction (see Fricker 2007, 67-72). ${ }^{2}$ He or she is a moral agent who does not uncritically hold onto his or her epistemic beliefs by shutting out a stronger counter-evidence from the other. Related to this is the idea of epistemic equity fostered by àgbájo owó. Unlike epistemic egalitarianism, which emphasizes that, all things being equal, every moral agent is epistemically worthy, or should be epistemically respected as much as the other epistemic equity emphasizes that every moral agent should actually be given as much opportunity as possible to perform epistemically or deliver the relevant epistemic good, apart from being merely epistemically respected.

\section{Likely Objections and Responses}

The basic objective here is to address the question of the feasibility of proposing àgbájọ owo as the collegial basis for deliberative democracy in Nigeria. This takes a two-fold approach. The first is to critically consider and respond to some likely objections to the thesis of àgbájo ọwọ as an instrumentality of collegiality within the democratic space in Nigeria, and the second is to give a framework of how to practically bring it about.

Perhaps, the first objection is ethno-cultural. The claim might be that the whole thesis of àgbájo owo as collegiality is ethno-culturally restrictive, that it is an emergent thinking from the Yoruba, and that even if it could be successfully brought about in the contextual democratic sense at all, it would only be democratically feasible within its ethno-cultural environment. In other words, given its ethno-cultural milieu, it would never be democratically acceptable to other ethno-cultural groups in Nigeria. This objection, it must be noted, is not really about whether or not the whole thesis is practicable at all; rather, it is about the question of extending the scope of its applicability This objection could be negated by noting that what matters most is not the ethno-cultural environment of the thesis; rather, it is its democratic value in practice. A thesis could emerge from any ethno-cultural environment; so long as it is democratically valuable, it seems rational to adopt it anywhere, even outside its environment of evolution. After all, liberal democracy is essentially a Western political notion; nevertheless, its practice is almost global. Here, we are concerned with its democratic significance in practice, if any, but not its environment of evolution.

Yet another objection to the thesis of àgbájo owo as collegiality might be that, just as any form of deliberative arrangement, it might naturally favor

2 Although, Fricker addresses something similar to the phrase, "good epistemic hearer," she does not use the concept; she actually does use "the responsible hearer." Moreover, the contextual conception of the phrase is the present author's. 
those, who are educated and articulate, those that really know what it takes to present their interests intelligibly and intelligently and equally marshal good reasons to support them. This objection may be countered by stating that the participants in the exercise of àgbájo ow wọ as collegiality, who do not belong to the so-called favored category, may be specially trained by relevant experts to understand and master the nuances and niceties of rational deliberation/ dialogue, so as to off-set their hitherto deficiencies. After the requisite training, subsequent constant practice makes them as good as those, who are educated and articulate.

Having examined and responded to some likely objections to the proposal of àgbájọ owọ́ as collegiality within the political sphere in Nigeria, the next pertinent issue concerns the significant question of a framework for the operationalization of the proposal, and this requires some systematically coordinated, goal-oriented steps:

First step: There must be an unambiguous clarity of the political goal or set of political goals or issues to be publicly deliberated upon. This is similar to the systematic effort of problem identification/definition in the study of public-policy making and implementation. Here, a political issue of note may revolve around the question of who is to be chosen among a welter of candidates to represent a party, say $X$, in a forthcoming election. In this context, all the candidates interested in representing $X$ are to be brought before what one would contextually call "the àgbájo ow ọ political forum," the forum of political deliberators, or the people's parliament, so to speak, who are to critically examine the moral and the epistemic capital of each of them, asking them relevantly searching questions, and thus arrive at the propriety of their individual candidature. It might be argued that people might not be interested in forming such a forum, that they would rather choose an option of political exit or deliberate de-politicization, given their distracting level of poverty, their distrust of political leaders, and the perception that their votes have never counted. This, obviously, is a strong point. ${ }^{3}$ Nevertheless, it could still be countered. Critically considered, the truth of this claim is not absolute. A people that have been repeatedly disappointed politically in Nigeria might get it right if they politically choose wisely. A very good forum through which wise political choices could be made is the proposed collegiality which deploys the àgbájo ow wọ philosophy. In fact, the problem of poverty could be positively addressed through wise choices of political candidates that are tested and found to possess both moral and epistemic capital.

Second step: There must also be an unbiased identification of the community of people, whose interests are involved, and who must democratically

3 The author profusely thanks the Guest Editor for raising this important point. 
have a say in how the issues are to be approached. In the example given above, the deliberators are to be chosen from the community of people, the candidates are to represent, if elected into public offices.

Third step: There must be a reliable and sufficient communication links with the clearly identified community of people, who are to deliberate upon the issues. Here both national languages and local dialects are appropriate for contact purposes.

Fourth step: There must be publicly conducive forums, with all the necessary communications facilities, where the requisite deliberations could be made on the issues involved.

Fifth step: As prescribed in the Second step, both national languages and local dialects are to be deployed for effective deliberative purposes at the forums. This, undoubtedly, extends the linguistic scope and diversity of the democratic deliberation as much as possible.

Sixth step: The rational outcomes of the deliberations are to be taken as democratically significant. For example, in the case of candidates wishing to represent $X$ above, the rational outcomes of the deliberations conducted, relative to the candidates, are to be taken as having a democratic force on who is to be finally chosen to represent $X$, but not the sectarian interests of a few influential party members, who may prefer to impose a given candidate, regardless of his or her propriety, on others, no matter the level of their moral and epistemic capital. If the rational outcomes of the deliberations have a binding democratic force, which supports candidate $Y$, as against candidates $X$ and $Z$, then the community of deliberators would not turn round later and say that they did not initially have an actual say in the choice of person in political position, if eventually elected, given that the process from which candidate $Y$ emerged for the political position, was fairly all-inclusive, within the relative context. This all-inclusivity guarantees intra-party democracy, which is a step above imposition of specific party candidates, on their colleagues, and subsequently on the generality of the people, who are only called upon to rubber-stamp the imposed candidates to occupy political positions, through equally covertly rigged elections. Moreover, if the noted all-inclusivity, guaranteed by the collegial value of àgbájo owó, is embraced and promoted across all political parties in Nigeria, then we would, all other things being equal, have a cream of political party candidates in Nigeria, who have been found worthy morally and epistemically, to choose from for exalted political positions.

\section{Conclusion}

In this work, an attempt has been made to propose the value of àgbájo ow wó, as a collegial instrument, to enthrone a deliberative democracy in Nigeria. The 
argument has been that, for a long time, the influence of what one could call the demos' factor has been covertly removed from the so-called liberal democratic practice in Nigeria. This avowal has been based on the fact of the rising influence of godfatherism in Nigeria's political space. However, the essay argues that, since godfatherism on most occasions enthrones political mediocrity, on the basis of sectarian interests, rather than political meritocracy, which appropriately delivers the common good, then it should be de-emphasized. To address the problem, the essay proposed that the value of àgbájo owó, as collegiality should be publicly embraced in Nigeria.

\section{Works Cited}

Adeoye, O. A. (2009). "Godfatherism and the future of Nigerian democracy," African Journal of Political Science and International Relations vol. 3 no. 6, 268-272.

Ajayi, A. T. and Ojo, E. O. (2014). "Democracy in Nigeria: Practice, Problems and Prospects," Developing Country Studies, vol. 4, no. 2, 107-125.

Albert, I. O. (2005). "Explaining 'godfatherism' in Nigeria Politics,"African Sociological Review, vol.9, no. 2, 79-105.

Aluaigba, T. M. (2016). "Democracy Deferred: The Effects of Electoral Malpractice on Nigeria's Path to Democratic Consolidation," Journal of African Elections, vol.15, no.2, pp. 136-158.

Aluaigba, T. M. (2002). "The irony of democracy: the Nigerian experience," Democracy in Nigeria's fourth republic: myths, realities, challenges and prospects, S. F. Kamilu (Ed). (Kano: Triumph Publishing Company).

Badru, R. O. (2017). Environmental Deficit and Contemporary Nigeria: Evolving an African Political Philosophy for a Sustainable Eco-Democracy. Being a research paper, presented at the Ecological Challenges Conference, University of Oslo, Norway, from $15^{\text {th }}-18^{\text {th }}$ February, 2017.

Badru, R.O. \& Oloruntobi, A. J. (2016). "Political Ethics and Democratic Sustainability in Nigeria: Exploring a Constructive Synergy," African Journal of Democracy \& Development, 3 (3\&4): 159-186 (Institute for Democracy, Governance, Peace and Development in Africa, IDGPA, Congo).

Cavanagh, J. B. (2010). Managing Collegiality: The Discourse of Collegiality in Scottish School Leadership. Being an Ed.D thesis, submitted at the Department of Educational Studies, Faculty of Education, University of Glasgow, Scotland, in July, 2010.

Coetzee, P. H. and Roux, A. P. J. (eds.) (2003). The African Philosophy Reader, $2^{\text {nd }}$ (London and New York: Routledge). 
Cohen, J. (2009). "Reflections on Deliberative Democracy," Thomas Christiano and John Christman (eds.) Contemporary Debates in Political Philosophy, (Malden, MA.: Blackwell Publishing), 247-263.

Coker, O. and Coker, A. (2009). "Cultural Exploration as Alternative Route to National Development: Insights from Yoruba Verbal Arts," KEMANUSIAAN 16, 1-11.

Cortina, A. (2010). "Communicative Democracy: A Version of Deliberative Democracy," Archives for Philosophy of Law and Social Philosophy, vol. 96, no. 2, 133-150.

Dasylva, A. O. (2016). “Glocalization of Yoruba Omoluabi Ideology," Yoruba Studies Review, vol. 1, no. 1, 65-84.

Dryzek, J. S. (2004). "Pragmatism and Democracy: In Search of Deliberative Publics," The Journal of Speculative Philosophy, New Series, vol. 18, no. 1, 72-79.

Fricker, M. (2007). Epistemic Injustice: Power and the Ethics of Knowing (Oxford: Oxford University Press).

Gaus, G. F. (2008). "The (Severe) Limits of Deliberative Democracy as the Basis for Political Choice," Theoria: A Journal of Social and Political Theory, no. 117, 26-53.

Gyekye, K. (2010). 'African Ethics,' Stanford Encyclopaedia of Philosophy.

Accessed on $8^{\text {th }}$ March, 2011, from 'http://plato.stanford.edu/entries/ african-ethics/

Hardin, R. (2009). "Deliberate Democracy," in Thomas Christiano and John Christman (eds.) Contemporary Debates in Political Philosophy (Malden, MA: Blackwell Publishing), 231-246.

Hicks, D. (2002). "The Promise(s) of Deliberative Democracy," Rhetoric and Public Affairs, vol. 5, no. 2, Special Issue on Deliberative Democracy (Summer), 223-260.

Joseph, R. (1999). Democracy and Pre-bendal politics in Nigeria: The Rise and Fall of the Second Republic. Ibadan: Spectrum Books.

Kura, S. B. (2014). "'Clientele Democracy': Political Party Funding and Candidate Selection," African Journal of Political Science and International Relations, vol. 8, no. 5, 124-137.

Ojo, A., (1978) "Iwa Omoluuabi," in Oludare Olajubu (ed.) Iwe Asa Ibile Yoruba (Ibadan: Longman Nig. Ltd.), 18-22.

Omotola, J.S. (2007). "Godfathers and the 2007 General Elections in Nigeria," Journal of African Elections: Special Issue: Nigeria's 2007 General Elections, vol.6, no. 2, pp. 134-154.

Osakede, K O. and Ijimakinwa, S. O. (2016). "Political Godfatherism and Democratic Consolidation in Nigeria: Empirical Evidence from Oyo State 
and Kwara State" Arabian Journal of Business and Management Review (OMAN Chapter). vol. 5, no.8; March, 1-12

Oyeyemi, R. (2016). The Collegiate Leadership Concept. Accessed on $26^{\text {th }}$ June, 2017, http://pointblanknews.com/pbn/articles-opinions/ collegiate-leadership-concept/

Van Hooft, S. (2011). "Socratic Dialogue as Collegial Reasoning," Society for Philosophy in Practice. Accessed on 17 th June, 2017, from 'http://www.practical-philosophy.org.uk/' (Originally published as: Socratic Dialogue as Collegial Reasoning. Practical Philosophy 2: 2 (July), pp.22-31). 